\title{
Root and leaf anatomy of some terrestrial representatives of the Cranichideae tribe (Orchidaceae)
}

\author{
Rita de Cássia Andreota • Fábio de Barros • \\ Maria das Graças Sajo
}

Received: 22 August 2014/ Accepted: 7 January 2015/Published online: 8 February 2015

(C) Botanical Society of Sao Paulo 2015

\begin{abstract}
The Orquidaceae family has more than 25,000 species, of which $20 \%$ are terrestrial Cranichideae mainly belonging to the tribe, which is inserted in Orchidoideae, one of the five subfamilies of the Orchidaceae. This group of terrestrial orchids presents a confusing taxonomy and is a poorly known group in terms of their vegetative anatomy in opposition to the epiphytic representatives that have been extensively investigated. This paper describes the root and leaf anatomy of ten species of Cranichideae tribe found in Brazil, belonging to subtribes Cranichidinae, Goodyerinae, and Spiranthinae, comparing their organization to those of the epiphytic plants. We also point out some features that can be useful for the characterization of each subtribe. The roots have studied characteristics that may assist in the absorption and retention of water as the occurrence of velamen and exodermis system, and in the presence of tilossomos Cranichidinae and Spiranthinae. The leaves are narrow with a homogeneous mesophyll, covered by uniseriate epidermis and covered by thin cuticle. The xylem cells are arranged in pairs or inverted $\mathrm{V}$-shape, as in the other orchids Cranichideae tribe.
\end{abstract}

Keywords Cranichidinae - Goodyerinae - Leaf anatomy · Root anatomy $\cdot$ Spiranthinae

R. de Cássia Andreota $(\varangle)$ · M. das Graças Sajo Departamento de Botânica, Instituto de Biociências, Universidade Estadual Paulista - UNESP, Avenida, 24 A, 1515, Bela Vista, Rio Claro, São Paulo CEP 13506-900, Brazil

e-mail: rcandreota@yahoo.com.br

F. de Barros

Instituto de Botânica, Secretaria Estadual do Meio Ambiente, Seção de Orquidário do Estado, Avenida, Miguel Estefano, 3687, Água Funda, São Paulo, São Paulo CEP 04301-012, Brazil

\section{Introduction}

The large and diversified family Orchidaceae, with more than 25,000 species in 780 genera (Pridgeon et al. 2009) of cosmopolitan distribution, (Pabst and Dungs 1975; Dressler 1993) belongs to the order Asparagales and is subdivided into five subfamilies: Apostasioideae, Vanilloideae, Cypripidioideae, Orchidoideae, and Epidendroideae (Pridgeon et al. 1999; Freudenstein and Rasmussen 1999; Chase et al. 2003). Although most of Orchidaceae are epiphytic, around $20 \%$ of its representatives belonging to the Cranichideae tribe (Orchidoideae) are terrestrial (Dressler 1993; Pridgeon et al. 1999). The Cranichideae, with six subtribes (Cranichidinae, Galleotiellinae, Goodyerinae, Manniellinae, Pterostylidinae, and Spiranthinae) (Pridgeon et al. 2003), is represented in Brazil by 34 genera and 260 species (Barros et al. 2013) included in the Cranichidinae, Goodyerinae, and Spiranthinae tribes (Pridgeon et al. 2003).

The taxonomy of the Cranichideae tribe has been controversial, especially regarding the limits between the subtribes Cranichidinae and Prescottiinae. For example, Dressler (1993) moved the genera Aa, Altensteinia, Gomphichis, Myrosmodes, Porphyrostachys, Prescottia, and Stenoptera, previously included in Cranichidinae, to Prescottiinae on the basis of features of the velamen, the structure of the pollinia, and the shape of the rostellum. However, as pointed out by Salazar et al. (2003), some features that segregate Prescottiinae from Cranichidinae are shared by representatives of other subtribes, such as the Spiranthinae, and probably represent symplesiomorphies for the group. Within Cranichideae, nonresupinate flowers are restricted to the Cranichidinae and Prescottiinae. Accordingly, Dressler (1981) considers them as a single group in his classification. Recent phylogenetic studies (Salazar 
et al. 2003, 2009; Álvarez-Molina and Cameron 2009) recognized Prescottiinae as a non-monophyletic clade with two distinct lineages, indicating that further investigations are necessary. The phylogenetic molecular analysis of Chase et al. (2003) included representatives of the Prescottiinae within the subtribe Cranichidinae, thus agreeing with Dressleŕs proposition (1981). The phylogenetic study of Salazar et al. (2003) resolved the subtribe Spiranthinae and Goodyerinae as monophyletic groups and highlighted the need for a re-evaluation of their morphological features, especially regarding flower structure, to better position these representatives.

Considering the current discussion of the limits of the Cranichideae subtribes (Dressler 1993; Kores et al. 1997; Chase et al. 2003; Salazar et al. 2003, 2009; Figueroa et al. 2008; Álvarez-Molina and Cameron 2009), the present study examines the vegetative organs of some of their representatives aiming to identify structural aspects related to their terrestrial habitat that may also prove useful for the taxonomic delimitation of the group.

\section{Materials and methods}

The material was collected from the living collection of the Seção do Orquidário do Instituto de Botânica de São Paulo (SP), the Jardim Botânico do IBB, UNESP (BOTU), Botucatu (SP) and in the Viveiro de Mudas Fundação Herminio Ometto, Araras (SP) where they are recorded as follows: Cranichis candida (Barb.Rodr.) Cogn. (18297), Prescottia oligantha (Sw.) Lindl. (18310) (subtribe Cranichidinae), Microchilus arietinus (Rchb.f. \& Warm) Ormerod (BOTU 028404), Zeuxine strateumatica (L.) Schltr. (907) (subtribe Goodyerinae), Cyclopogon apricus (Lindl.) Schltr. (BOTU 028450), Cyclopogon congestus (Vell.) Hoehne (VFHO 138), Cyclopogon variegatus Barb.Rodr. (BOTU 028380), Mesadenella cuspidata (Lindl.) Garay (BOTU 028401, 17258), Pteroglossa roseoalba (Rchb.f.) Salazar \& MW Chase (IBB-UNESP 0653), and Sauroglossum nitidum (Vell.) Schltr. (P3653, P3658) (subtribe Spiranthinae).

For anatomical analysis, roots and fully developed leaves were fixed in FAA 50 and stored in $50 \%$ alcohol (Johansen 1940). They were freehand cross-sectioned, stained with Astra blue and Safranin (Bukatsch 1972), and mounted in glycerol. Permanent slides were obtained by dehydrating samples in alcohol series and embedded in Historesin $\left(\right.$ Leica $\left.^{\circledR}\right)$. The embedded samples were sectioned using a rotary microtome $(10-12 \mu \mathrm{m}$ thick); the sections were then stained with Periodic acid-Schiff reagent (PAS) and toluidine blue (Feder and O'Brien 1968) and mounted in Permount resin. Sections were examined using a Leica ${ }^{\circledR}$ DM4000B microscope coupled to an image capture system (Leica DFC450) that enabled measurement of root diameter, with Leica Application Suite (LAS) version 4.0.

For examination under a scanning electron microscope (Hitashi TM3000), fixed roots and leaves were dehydrated in alcohol series, dried in a critical point dryer (Balzers CPD 030), and sputter-coated with gold (Balzers SCD 050). This study was conducted in the Laboratory of Electron Microscopy of the Rio Claro Câmpus, UNESP.

\section{Results}

Roots

All roots are cylindrical and possess a specialized epidermis (velamen), a parenchymatous cortex, and a vascular cylinder (Figs. 1, 2, 3, 4, 5, 6), although the organ diameter varies according to the species. The root diameter is higher in the representatives of the subtribe Spiranthinae (Figs. 5, 6) and P. oligantha (Cranichidinae) (Fig. 2) and smaller in the Goodyerinae species (Figs. 3, 4) and in C. candida (Cranichidinae) (Fig. 1).

Except for S. nitidum (Spiranthinae) with a multilayered velamen (5-8 layers, Figs. 6, 9), the roots in the Spiranthinae are covered by a velamen of 1-2 layers (Fig. 5). A velamen of 1-2 layers is also present in $P$. oligantha (Cranichidinae) (Figs. 2, 8), while a one-layered velamen was observed in the subtribe Goodyerinae (Figs. 3, 4) and in the Cranichidinae $C$. candida (Figs. 1, 7). The velamen cells are polygonal or rectangular in cross section, but in $S$. nitidum (Spiranthinae) they are radially elongated (Fig. 9). They possess periclinal thickened walls with occasional linear parietal thickening in Cranichidinae and Spiranthinae (Figs. 7, 9, 10, 13). Some roots, like those of P. oligantha (Cranichidinae) and $S$. nitidum (Spiranthinae), possess an epivelamen of periclinally flattened cells (Fig. 8).

The exodermis, the outer layer of the root cortex, is formed by polygonal or rectangular cells with scalariformthickened anticlinal walls (Figs. 9, 10, 12) in the Cranichidinae and Spiranthinae species. In Z. strateumatica, the exodermis is not morphologically distinct (Fig. 4).

Specialized thickenings on the passage cells of the exodermis, named tilosomes, occur in P. oligantha (Cranichidinae) and Spiranthinae species (Figs. 8, 11, 12, 13).

Internally to the exodermis, there is a parenchymatous cortex with numbers of layer that vary according to the species. Clusters of endomycorrhiza are frequent in the cortex of all roots. Usually, they are few and restricted to the peripheral region, but in M. arietinus and Z. strateumatica (Goodyerinae), they are distributed throughout the cortex (Figs. 3, 4, 14). All studied roots possess idioblasts 


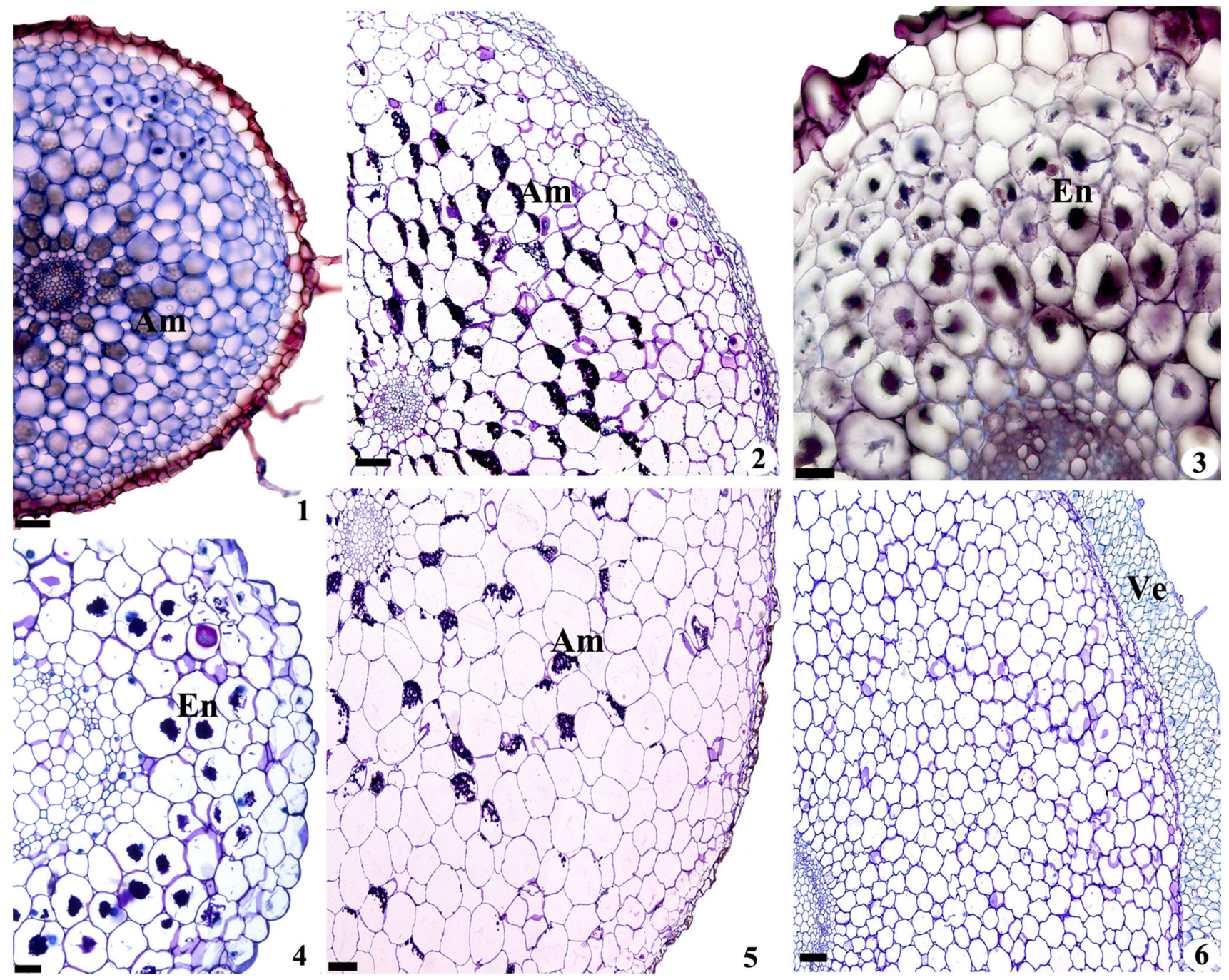

Figs. 1-6 Cross section of the roots showing the general structure. 1 Cranichis candida. 2 Prescottia oligantha. 3 Microchilus arietinus. 4 Zeuxine strateumatica. 5 Cyclopogon variegatus. 6 Sauroglossum nitidum. Am amyloplasts, En endomycorrhizas, Ve velamen. Bar = $100 \mu \mathrm{m}(1) ; 200 \mu \mathrm{m}(2,5,6) ; 50 \mu \mathrm{m}(3,4)$ with raphides of calcium oxalate in the cortex (Figs. 15, 16), and starch grains occur in the subtribe Cranichidinae and Spiranthinae species (Figs. 1, 2, 5, 17, 18). In Spiranthinae, there are thick-walled cells scattered throughout the cortex (Fig. 19). The inner cortex layer, endodermis, is formed by isodiametric thin-walled cells with an evident Casparian strip, in all roots (Figs. 20, 22, 23).

The limit between the cortex and the vascular cylinder is composed of a thin-walled uniseriate pericycle. All roots are polyarcs with the number of protoxylem poles varying from 5 to 6 in C. candida (Cranichidinae) (Fig. 20) to 13-15 in S. nitidum (Spiranthinae) (Fig. 21). The root center is filled by thin-walled parenchymatous cells (Figs. 16, 20, 21, 22, 23). In this region, idioblasts with raphides and starch grains are common.
Leaves

All leaves are covered on both surfaces by a thin cuticle and a one-layered epidermis of polygonal, rectangular, or rounded cells (Figs. 24, 25, 26, 27, 28, 29, 30, 31, 32). In the Goodyerinae representatives, as exemplified by $M$. arietinus, the epidermal cells are papillose, on both sides of the leaf (Figs. 26, 33), while in Z. strateumatica only on the adaxial leaf surface (Fig. 27). Papillose cells on the adaxial leaf surface also occur in C. variegatus from the Spiranthinae (Figs. 31,34) and on the blades of $P$. roseoalba (Figs. 32, 35). In P. oligantha (Cranichidinae), $Z$. strateumatica (Goodyerinae), $C$. apricus, $C$. variegatus, and $P$. roseoalba (Spiranthinae), the epidermal cells of the adaxial surface are more developed than those of the abaxial ones (Figs. 25, 27, 30, 31, 32). 

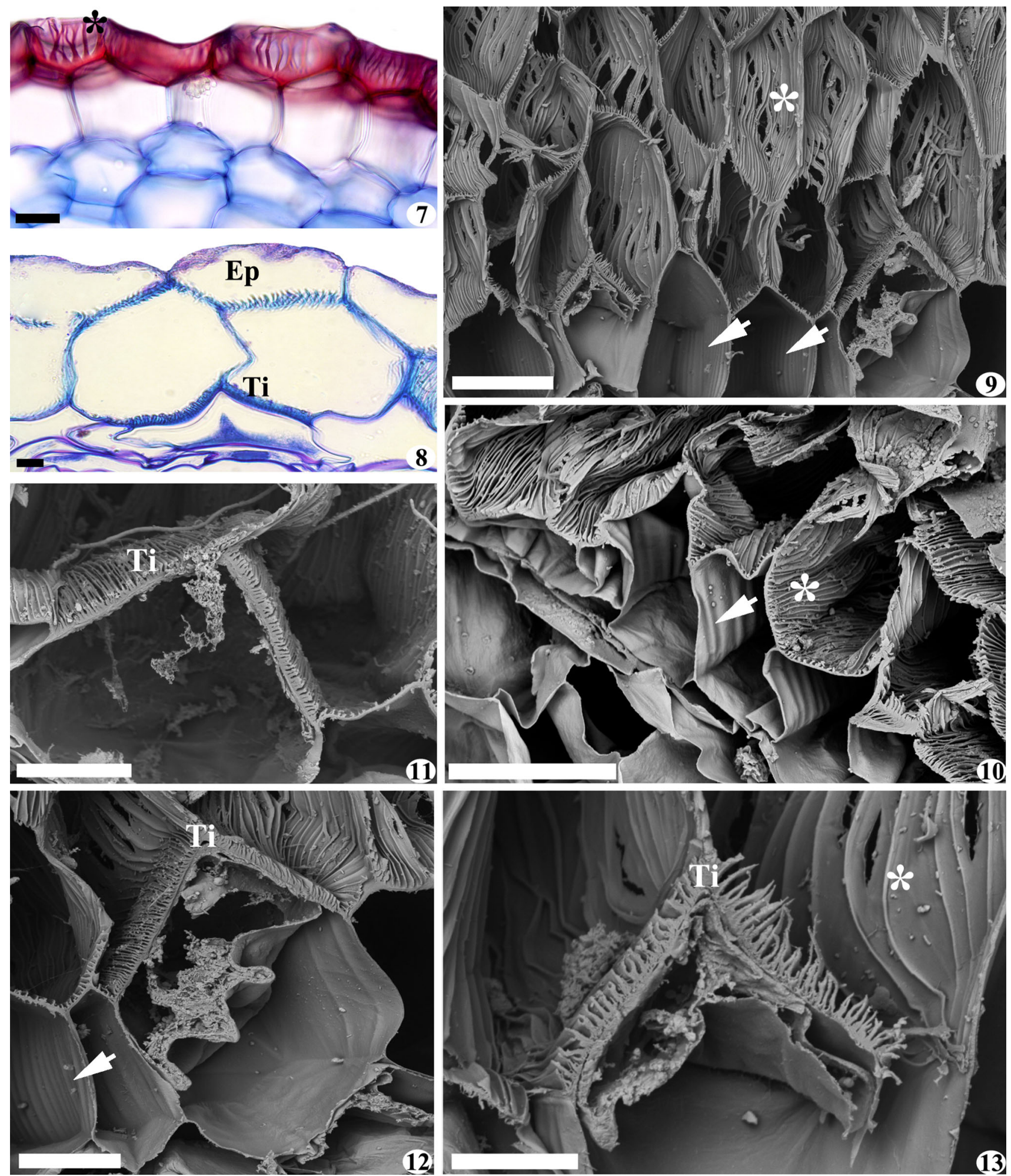

Figs. 7-13 Structural characters of velamen. 7 Cranichis candida. 8, 10 Tilosome and linear thickening of Prescottia oligantha (SEM). 9, 12, 13 Tilosome and linear thickening of Sauroglossum nitidum

(SEM). 11 Tilosome of Cyclopogon congestus (SEM). Ep epivelamen, $T i$ tilosomes, * linear thickening, arrows scalariform thickened. Bar $=25 \mu \mathrm{m}(7,11,12) ; 10 \mu \mathrm{m}(8) ; 50 \mu \mathrm{m}(9,10) ; 15 \mu \mathrm{m}(13)$

On the surface view, the epidermal cells are polygonal of straight or slightly sinuous walls, in all species (Figs. 33, $34,35,36,37,38,39,40,41,42,43,44,45,46,47)$. The

wax covering the leaves forms strips in $M$. arietinus and $Z$. strateumatica (Goodyerinae) (Figs. 39, 40) and granules in C. congestus and S. nitidum (Spiranthinae) (Figs. 41, 42). 
All leaves are hypostomatic except for $C$. apricus (Spiranthinae) that has stomata on both surfaces (Figs. 30, 43, 44). The stomata are anomocytic in $Z$. strateumatica (Goodyerinae) (Fig. 40) and anisocytic, paracytic, and diacytic in the remaining studied species (Figs. 39, 41, 42, $43,44,45,46,47)$. They are positioned on the same level or slightly above the epidermal cells and possess conspicuous projections forming ridges above the opening, forming a suprastomatal chamber. Both the outer and the inner periclinal walls of the guard cells are thickened (Figs. 48, 49, 50).

The mesophyll in all leaves is homogeneous, with a spongy parenchyma (Figs. 24, 25, 26, 27, 28, 29, 30, 31, $32,51,52,53,54)$. The mesophyll thickness varies according to the species, being 3-4 layered in C. candida (Cranichidinae) (Fig. 53) and 8-9 layered in C. congestus and S. nitidum (Spiranthinae) (Fig. 54). Raphides of calcium oxalate are randomly distributed in the mesophyll of all species (Figs. 51, 52). The vascular bundles, of variable size, are collateral and disposed in the median region of the mesophyll. They are surrounded by a one-layered endodermis of thin-walled cells similar to those of the mesophyll (Figs. 51, 53, 54). In the midrib region, there is a single collateral bundle with the xylem cells arranged in an inverted $\mathrm{V}$ (Fig. 55) or forming sets separated by parenchyma cells (Fig. 56). There is no collenchyma in the midrib region in all studied leaves.

\section{Discussion}

\section{Roots}

Most of the roots are thick and fleshy, as described for other terrestrial orchids (Stern et al. 1993b; Figueroa et al. 2008; Moreira and Isaias 2008; Dugarte-Corredor and Luque-Arias 2012). This feature, according to Zotz (1999), can promote an increase in water and nutrients storage (Dressler 1993), particularly, as the species studied here, if the plant lacks specialized organs, like fleshy leaves and/or pseudobulbs. In the subtribe Goodyerinae, the roots are thin, but there is a stem axis that could help in the storage function (Ormerod 2009; Menini Neto et al. 2011).

All roots are covered by a specialized epidermis, the velamen, that improves water and nutrients absorption and reduces the water loss through transpiration (Dycus and Knudson 1957; Sanford and Adanlawo 1973; Benzing et al. 1982, 1983; Pridgeon 1987). According to Pridgeon (1987), the velamen cell walls are cellulosic and can be impregnated with lignin and suberin in varying degrees, providing a mechanical support that prevents the cell from collapsing during desiccation (Noel 1974). Like other terrestrial species of the Cranichideae tribe (Stern et al. 1993b; Figueroa et al. 2008; Dugarte-Corredor and LuqueArias 2012), the outer walls of the velamen cells in all studied roots are thickened and possess an additional linear thickening in the Cranichidinae and Spiranthinae species. Variable thickenings in the velamen cell walls were also reported by Figueroa et al. (2008) for Cranichideae. In the same study, the authors described the velamen cells of Goodyera brachycera as without any evident thickening, as observed here for the species belonging to the same subtribe (Goodyerinae).

According to Sanford and Adanlawo (1973), the cells of the outer velamen layer, the epivelamen, can be smaller and less lignified when compared to the inner ones. These features were observed for both $P$. oligantha (Cranichidinae) and $S$. nitidum (Spiranthinae). Porembski and Barthlott (1988) classified orchid roots into different types according to the presence or absence of an epivelamen, the number of the velamen layers, the thickening shape of the velamen and exodermis cell walls, and the organization of the cortex. In most of the species studied here, the roots, with a narrow velamen (one or two-layers) and without a differentiated epivelamen, are of the Spiranthes type, agreeing with other studies on terrestrial orchids (Stern et al. 1993b; Stern 1997a, b; Figueroa et al. 2008; DugarteCorredor and Luque-Arias 2012). The roots of the Goodyerinae representatives do not fit into any specific type, fitting the description of the "simple rhizodermis" of Porembski and Barthlott (1988).

The occurrence of a developed velamen (5-8 layers) in $S$. nitidum may be explained by the fact that this species grows in dryer open environments that can cause an increase in the rate of water loss. According to Sanford and Adanlawo (1973), the availability of water and the temperature can affect the features of the velamen cells in such way that species growing in dry environments or open areas tend to exhibit a velamen with several layers of thickened cells, while those growing in wet sites possess a narrow often one-layered velamen (Pridgeon 1987; Engard 1944).

Specialized structures in the inner periclinal walls of the velamen cells positioned adjacent to the exodermis passage cells, the tilosomes, were found in P. oligantha and in the representatives of the subtribe Spiranthinae, as reported for Cranichidinae (Figueroa et al. 2008). Although already described for various terrestrial representatives (Benzing et al. 1982; Figueroa et al. 2008 and the present study), the tilosomes have been associated with the epiphytic habit (Pridgeon et al. 1983; Porembski and Barthlott 1988). Such structures, also called coverage cells, improve the extent of water condensation and thus improve its uptake (Benzing et al. 1982; Pridgeon et al. 1983; Pridgeon 1987; Engard 1944).Tilosomes are formed of many channels that expand when hydrated to allow the entrance of water, then collapse 

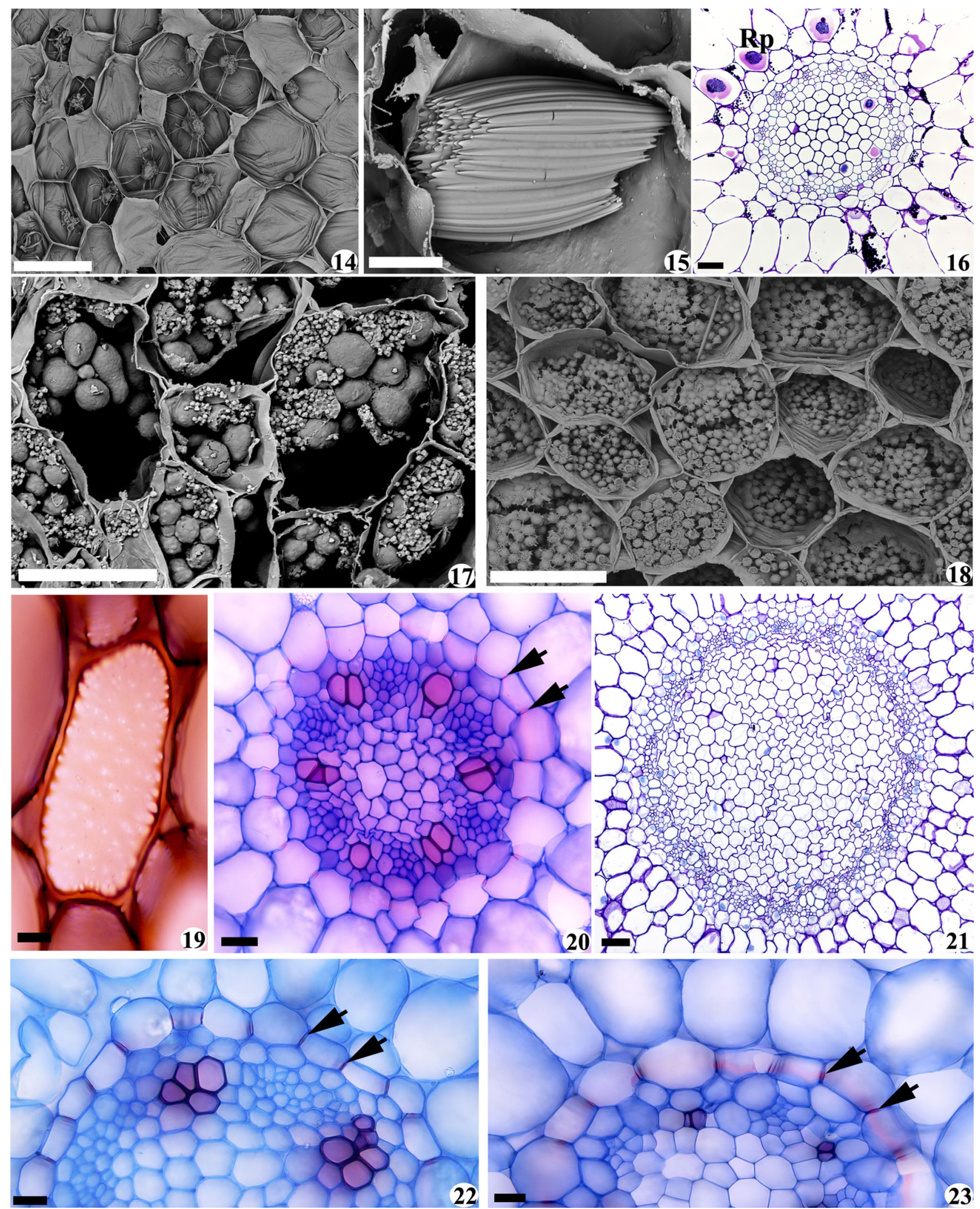
4Figs. 14-23 Root in cross section showing cortical and pith parenchyma. 14 Endomycorrhizas of Zeuxine strateumatica (SEM). 15 Raphide of Pteroglossa roseoalba (SEM). 16 Central cylinder of Mesadenella cuspidata. 17, 18 Cortical cells with spiranthosomes of Cranichis candida (SEM) and Sauroglossum nitidum (SEM), respectively. 19 Thick-walled cells of Pteroglossa roseoalba. 20, 22, 23 Central cylinder with Casparian strip of Cranichis candida, Cyclopogon apricus, and Cyclopogon variegatus, respectively. 21 Central cylinder of Sauroglossum nitidum. Rp raphides, arrows Casparian strip. $B a r=150 \mu \mathrm{m}(14) ; 25 \mu \mathrm{m}(15,19,20,22,23) ; 100 \mu \mathrm{m}(16,18$, 21); $50 \mu \mathrm{m}(17)$

when the plant faces a desiccation, slowing the rate of water loss (Benzing et al. 1982; Pridgeon et al. 1983).

Within the velamen, the root cortex is limited by the exodermis, which is one layered and formed by thin-walled cells. In Cranichidinae and Spiranthinae roots, the exodermis cells also possess scalariform-thickened walls, as described for other representatives of the tribe Cranichideae (Stern et al. 1993b; Figueroa et al. 2008; Dugarte-Corredor and Luque-Arias 2012). These thickenings form a rigid structure that may serve to resist the cells collapsing, thus reducing water loss (Stern et al. 1993b; Figueroa et al. 2008).

Endomycorrhizas, commonly found in the Orchidaceae roots (Hadley 1982; Zotz 1999), occur in all species, as in other terrestrial representatives (Stern et al. 1993b; Dugarte-Corredor and Luque-Arias 2012). They increase the rate of nutrient absorption and can be a source of nutrients when digested by the host (Arditti 1967; Dressler 1981; Hadley 1982; Benzing et al. 1983).

Idioblasts with raphides of calcium oxalate, which occur in the root cortex of all species studied, can perform variable functions such as osmoregulation, calcium storage, or regulation of calcium levels in the sieve elements. They may also serve to increase defense against herbivory (Bonates 1993; Franceschi and Nakata 2005).

In the representatives of Cranichidinae and Spiranthinae, there are specialized amyloplasts, named spiranthosomes that constitute a synapomorphy for the tribe Cranichideae. Spiranthosomes are spherical bodies with two limiting membranes that enclose tiny grains of starch and are associated with storage of nutrients (Stern et al. 1993a). In this same study, roots with many packs of hyphae were devoid of spiranthosomes. This could explain why they are absent in the Goodyerinae studied here.

In the root cortex of the Spiranthinae representatives, some cells are thick walled. These cells can improve the water storage by providing mechanical support, thus avoiding cell collapse during dry periods (Olatunji and Nengim 1980; Pridgeon 1982; Benzing et al. 1983; Sinclair 1990). They have received different names, such as tracheoid idioblasts (Olatunji and Nengim 1980; Benzing et al. 1983), idioblasts with spiral thickening (Pridgeon 1982), and thickened bars (Bonates 1993). The vascular cylinder is polyarc, and according to Luque (2004), this feature is related to a more efficient transport, of water and

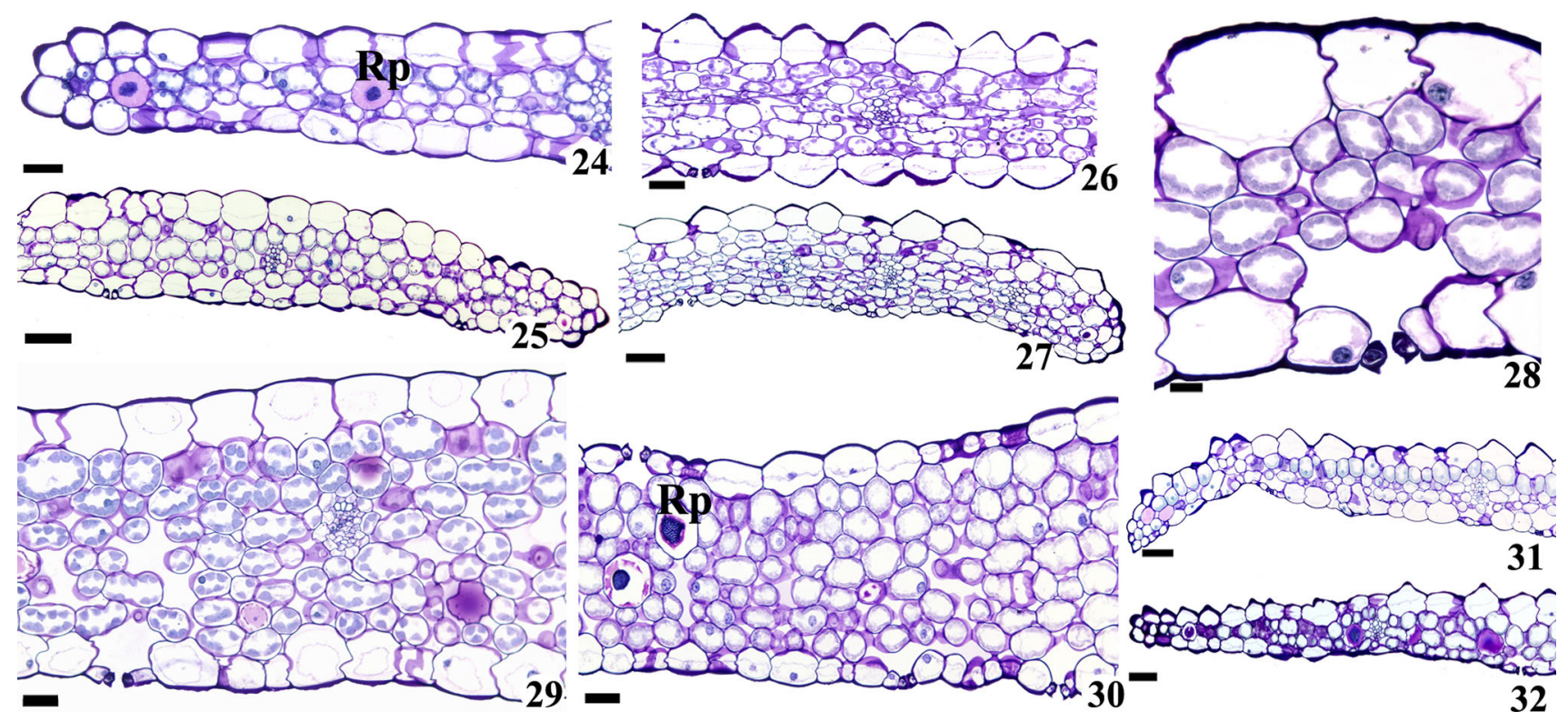

Figs. 24-32 Leaves in cross section showing the epidermal cells and mesophyll. 24 Cranichis candida. 25 Prescottia oligantha. 26 Microchilus arietinus. 27 Zeuxine strateumatica. 28 Sauroglossum nitidum. 29 Mesadenella cuspidata. 30 Cyclopogon apricus. 31 Cyclopogon variegatus. 32 Pteroglossa roseoalba. Rp raphides. Bar $=50 \mu \mathrm{m}(24,26,29,30) ; 100 \mu \mathrm{m}(25,27,31,32) ; 25 \mu \mathrm{m}(28)$ 


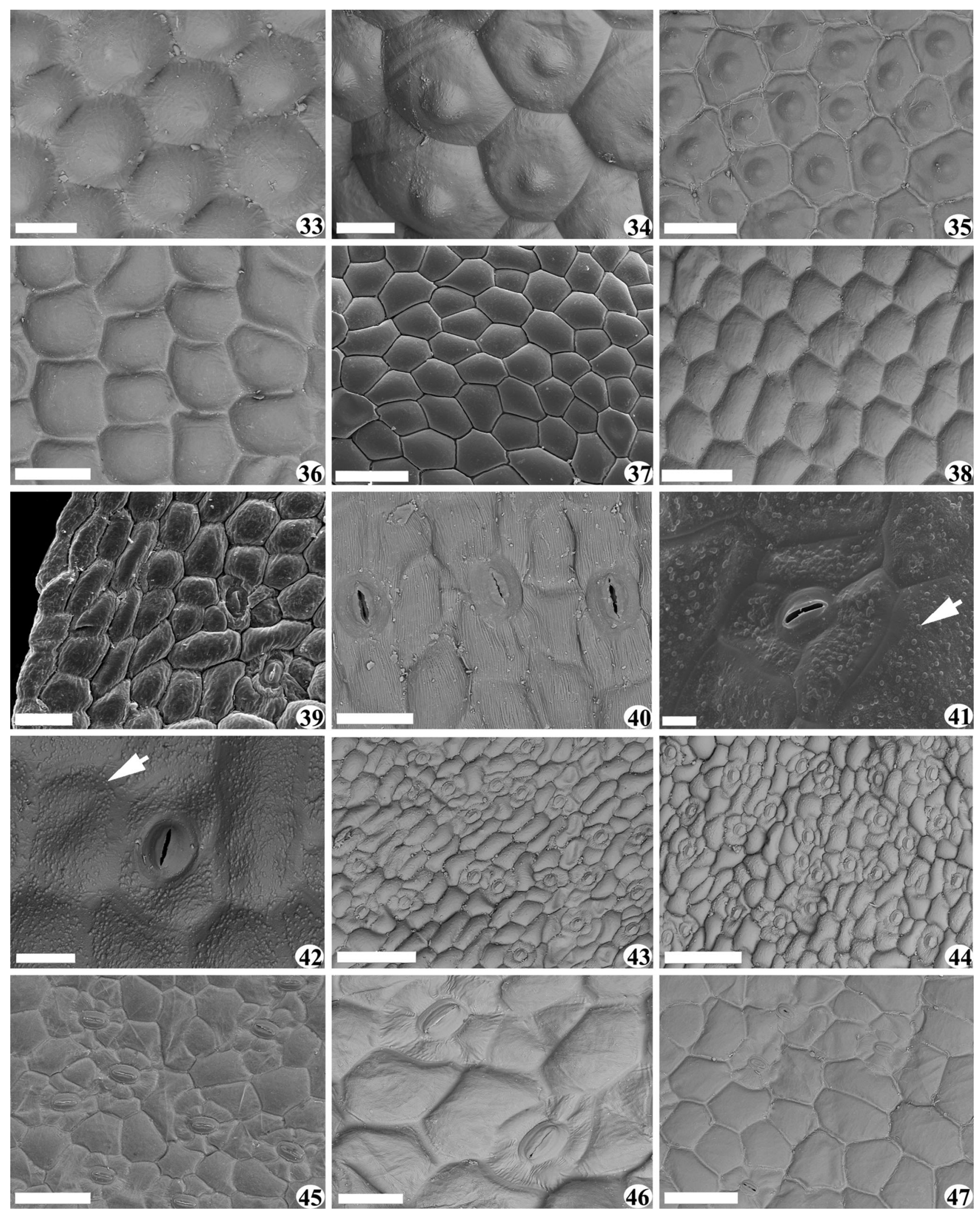


4Figs. 33-47 Frontal view of leaf surface (SEM). 33-36 Papillose cells of adaxial surfaces of Microchilus arietinus, Cyclopogon variegatus, Pteroglossa roseoalba, and Zeuxine strateumatica, respectively. 37, 38 Adaxial surfaces of Prescottia oligantha and Mesadenella cuspidata, respectively. 39, 40 Strips of abaxial surfaces of Microchilus arietinus and Zeuxine strateumatica, respectively. 41, 42 Granules of abaxial surfaces of Cyclopogon congestus and Sauroglossum nitidum, respectively. 43, 44 Amphistomatous leaf Cyclopogon apricus, adaxial and abaxial surfaces. 43-47 Many types of stomata of Cyclopogon apricus, Cranichis candida, Mesadenella cuspidata, and Pteroglossa roseoalba, respectively. Arrow granules. Bar $=50 \mu \mathrm{m}(33,34,39,40,42,46) ; 150 \mu \mathrm{m}(35,38,43,44,47)$; $100 \mu \mathrm{m}(36,37,45) ; 20 \mu \mathrm{m}(41)$

nutrients, to the xylem leading to their rapid conduction. The root center is filled with parenchyma cells with thin walls, a feature described for other orchids (Stern et al. 1993b; Figueroa et al. 2008; Moreira and Isaias 2008; Dugarte-Corredor and Luque-Arias 2012).
Leaves

Like in other terrestrial orchids, the leaves of the species studied are hypostomatic and covered by a thin cuticle. A thicker cuticle covers the leaves of the Spiranthinae representatives. Cuticle thickness has been related to the degree of exposure to the sun, with the more exposed leaves having thicker cuticles (Bonates 1993; Oliveira and Sajo 1999; Zanenga-Godoy and Costa 2003; Silva et al. 2006). It also may be related to the water relations (Mauseth 1988). Typically, species growing in shady places have thin cuticles and those found in sunny areas have thicker cuticles (Oliveira and Sajo 1999; Silva et al. 2006). These features may explain why $S$. nitidum that grows in open areas possesses leaves covered by a thicker cuticle when compared to the remaining species living in shady environments. In the Goodyerinae, M. arietinus, and Z. strateumatica, the cuticle is striated and in the Spiranthinae, $C$.
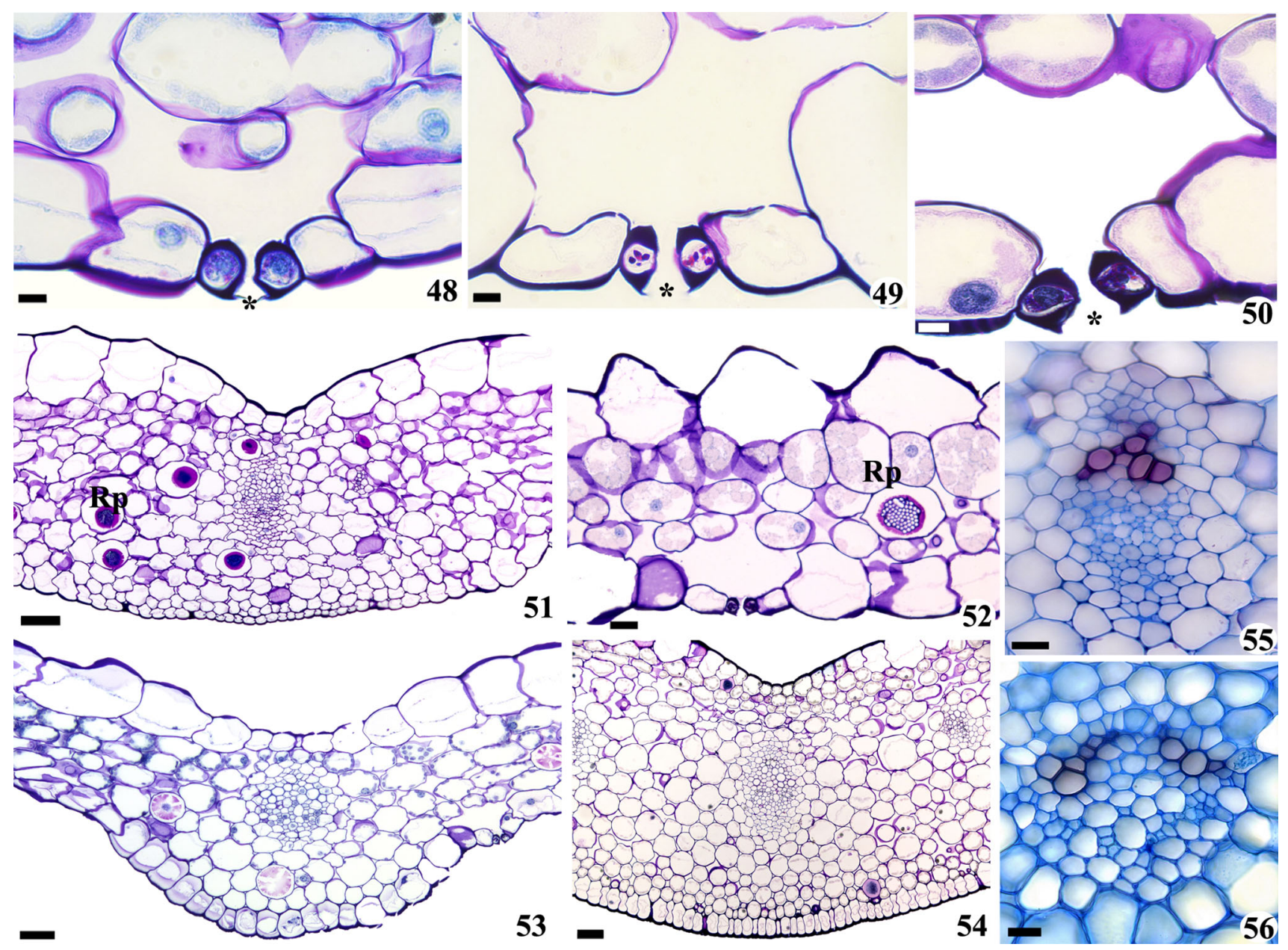

Figs. 48-56 Cross section of leaves, details of mesophyll. 48-50 Suprastomatal chamber of Prescottia oligantha, Pteroglossa roseoal$b a$, and Sauroglossum nitidum, respectively. 51, 53, 54 Vascular bundles disposed in the median region of the mesophyll of Pteroglossa roseoalba, Cranichis candida, and Sauroglossum nitidum, respectively. 52 Raphides of Cyclopogon apricus. 55 Xylem cells arranged in pairs of Prescottia oligantha. 56 Xylem cells arranged in inverted V-shape of Zeuxine strateumatica. Rp raphides, * suprastomatal chamber. Bar $=10 \mu \mathrm{m}(48,50) ; 100 \mu \mathrm{m}(51,54)$; $25 \mu \mathrm{m}(52,55,56) ; 50 \mu \mathrm{m}(53)$ 
congestus, and S. nitidum, the cuticle wax forms granules confirming the taxonomic value of the cuticle shape, as pointed out by Wilkinson (1979).

All studied leaves are covered by a one-layered epidermis. In P. oligantha (Cranichidinae) and in Z. strateumatica (Goodyerinae), C. apricus, $C$. variegatus, and $P$. roseoalba (Spiranthinae), the epidermal cells of the adaxial surface are larger than those of the abaxial ones, as described for terrestrial Habenaria (Stern 1997b; Silva et al. 2006) and for other orchids (Stern et al. 1993b; Oliveira and Sajo 1999). Enlarged epidermal cells may be related to water storage, especially when the plant is under hydric stress (Kurzweil et al. 1995; Oliveira and Sajo 1999). In Z. strateumatica (Goodyerinae) leaves, the enlarged adaxial epidermal cells are papillose and in M. arietinus (also a Goodyerinae), there are epidermal papillose cells on both surfaces, suggesting that this feature predominates in the subtribe, although it was also reported for some Cranichidinae (Dugarte-Corredor and Luque-Arias 2012). Papillose epidermal cells can work as lenses focusing and directing the incident light to the assimilative mesophyll cells (Wilkinson 1979).

With the exception of the amphistomatous C. apricus, all leaves are hypostomatous, as reported for other orchids (Rasmussen 1987; Oliveira and Sajo 1999; Zanenga-Godoy and Costa 2003). Stomata are common on both leaf surfaces in fleshy leaves exposed to high light intensities, a factor related to their role in water conservation (Parkhurst 1978). However, this does not seem to be the case in $C$. apricus that has leaves with a narrow mesophyll.

The stomata, positioned on the same level as the other epidermal cells or slightly above them, possess cuticular projections forming a suprastomatal chamber. These projections are often found in epiphytes and xerophytic orchids (Stern et al. 1993b; Oliveira and Sajo 1999; Silva et al. 2006; Dugarte-Corredor and Luque-Arias 2012) and form a moist air compartment that reduces the rate of transpiration (Rasmussen 1987). The stomata are anomocytic, anisocytic, paracytic, or diacytic, confirming the observations of Rasmussen (1987), Stern and Judd (2002), and Silva and Milaneze-Gutierre (2004), who have described the occurrence of many types of stomata on orchids leaves.

The mesophyll is homogeneous, without differentiation into palisade and spongy parenchyma, and consists of few layers, as observed by Stern et al. (1993b) for other Cranichideae. However, it does not correspond to the structures reported for Aa paleacea, Myrosmodes paludosa, and Pterychis multiflora (of the subtribe Cranichidinae) that have a differentiated mesophyll (Dugarte-Corredor and Luque-Arias 2012).

Like in other representatives of the family (Pridgeon 1982; Bonates 1993; Stern et al. 1993b; Pridgeon 1994;
Oliveira and Sajo 1999; Zanenga-Godoy and Costa 2003; Silva et al. 2006; Dugarte-Corredor and Luque-Arias 2012), most of the studied leaves possess idioblasts with raphides of calcium oxalate in the mesophyll. These crystals, related to the processes of osmoregulation and the ionic balance of the plants (Bonates 1993), also make them less palatable to animals, reducing rates of predation (Mauseth 1988; Franceschi and Nakata 2005).

In the midrib region, there is a single vascular bundle surrounded by parenchymatous cells, as described for some Cranichideae (Stern et al. 1993b, Dugarte-Corredor and Luque-Arias 2012) and for species of Habenaria and Prescottia montana (Silva et al. 2006). The xylem cells are arranged in an inverted $\mathrm{V}$ or form pairs separated by parenchymatous cells, features considered by Stern et al. (1993b) as particular for the tribe.

Although they are not epiphytes, the species studied here possess features which are recognized as adaptations to aid water absorption and retention, like the velamen and exodermis system present in all roots, besides the tilosomes found in the Cranichidinae and Spiranthinae species. However, these features are common in the Orchidaceae, implying that they were selected early during the evolutionary history of the family.

However, the leaves of the species studied do not have features related to water storage and protection against dehydration, suggesting that they do not face a constant hydric stress. The leaves are similar in related species, like some representatives of the subtribes Goodyerinae and Spiranthinae. This indicates possible synapomorphies within the groups, although a more detailed investigation is necessary to establish this possibility.

Acknowledgments The authors thank the Prof. Edwin W. Taylor for the English revision of this manuscript and the FAPESP (Fundação de Amparo à Pesquisa do Estado de São Paulo) for the financial support (2011/04474-1). MG Sajo thanks CNPq (Conselho Nacional de Desenvolvimento Científico e Tecnológico) for the fellowship.

\section{References}

Álvarez-Molina A, Cameron KM (2009) Molecular phylogenetics of Prescottiinae sl and their close allies (Orchidaceae, Cranichideae) inferred from plastid and nuclear ribosomal DNA sequences. Am J Bot 96:1020-1040

Arditti J (1967) Factors affecting the germination of orchid seeds. Bot Rev 33:1-97

Barros F, Vinhos F, Rodrigues VT, Barberena FFVA, Fraga CN, Pessoa EM, Forster W, Menini Neto L (2013) Orchidaceae. In: Forzza RC et al (coords.). Lista de espécies da flora do Brasil. Jardim Botânico do Rio de Janeiro. http://floradobrasil.jbrj.gov. br. Accessed 19 March 2014

Benzing DH, Ott DW, Friedman WE (1982) Roots of Sobralia macrantha (Orchidaceae): structure and function of the velamenexodermis complex. Am J Bot 69:608-614 
Benzing DH, Friedman WE, Peterson G, Renfrow A (1983) Shootlessness, velamentous roots, and the pre-eminence of Orchidaceae in the epiphytic biotope. Am J Bot 70:121-133

Bonates LCM (1993) Estudos ecofisiológicos de Orchidaceae da Amazônia II: anatomia ecológica foliar de espécies com metabolismo CAM de uma campina da Amazônia Central. Acta Amaz 23:315-348

Bukatsch F (1972) Bemerkungen zur Doppelfärbung AstrablauSafranin. Mikrokosmos 61:255-256

Chase MW, Cameron KM, Barret RL, Freudenstein JV (2003) DNA data and Orchidaceae systematics: a new phylogenetic classification. In: Dixon KW, Kell SP, Barret RL, Cribb PJ (eds) Orchid conservation. Natural History Publications, Kota Kinabalu, pp 69-89

Dressler RL (1981) The orchids: natural history and classification. Harvard University, Cambridge

Dressler RL (1993) Phylogeny and classification of the Orchid family. Dioscorides Press, Oregon

Dugarte-Corredor BA, Luque-Arias R (2012) Morfoanatomía en Cranichideae (orchidaceae) de la Estación Loma Redonda del Parque Nacional "Sierra Nevada", Mérida, Venezuela. Lankesteriana 12:61-75

Dycus AM, Knudson L (1957) The role of the velamen of the aerial roots of orchids. Bot Gaz 119:78-87

Engard CJ (1944) Morphological identity of the velamen and exodermis in orchids. Bot Gaz 105:457-462

Feder N, O'Brien TP (1968) Plant microtechnique: some principles and new methods. Am J Bot 55:123-142

Figueroa C, Salazar GA, Zavaleta HA, Engleman EM (2008) Root character evolution and systematics in Cranichidinae, Prescottiinae and Spiranthinae (Orchidaceae, Cranichideae). Ann Bot 101:509-520

Franceschi VR, Nakata PA (2005) Calcium oxalate in plants: formation and function. Annu Rev Plant Biol 56:41-71

Freudenstein JV, Rasmussen FN (1999) What does morphology tell us about orchid relationships? A cladistic analysis. Am J Bot $86: 225-248$

Hadley G (1982) Orchid mycorrhiza. In: Arditti J (ed) Orchid biology: reviews and perspectives II. Cornell University Press, Ithaca, pp 84-118

Johansen DA (1940) Plant microtechnique. McGraw-Hill Book Company, New York, p 523

Kores PJ, Cameron KM, Molvray M, Chase MW (1997) The phylogenetic relationships of Orchidoideae and Spiranthoideae (Orchidaceae) as inferred from rbcL plastid sequences. Lindleyana 12:1-11

Kurzweil H, Linder HP, Stern WL, Pridgeon AM (1995) Comparative vegetative anatomy and classification of Diseae (Orchidaceae). Bot J Linn Soc 117:171-220

Luque RA (2004) Estructura primaria del sistema radical de Coespeletia cuatrec. Interciência 29:13-18

Mauseth JD (1988) Plant anatomy. Benjamin/Cummings Publishing Company, California

Menini Neto L, Miranda MR, Cruz D (2011) Zeuxine strateumatica (Orchidaceae) goes south: a first record for Brazil. Kew Bull 66:155-158

Moreira ASFP, Isaias RMS (2008) Comparative anatomy of the absorption roots of terrestrial and epiphytic orchids. Braz Arch Biol Technol 51:83-93

Noel ARA (1974) Aspects of cell wall structure and development of the velamen in Ansellia gigantea Reichb.f. Ann Bot 38:495-504

Olatunji OA, Nengim RO (1980) Occurrence and distribuition of tracheoidal elements in the Orchidaceae. Bot J Linn Soc 80:357-370

Oliveira VC, Sajo MG (1999) Anatomia foliar de espécies epífitas de Orchidaceae. Rev Bras Bot 22:365-374
Ormerod P (2009) Studies of neotropical Goodyerinae (Orchidaceae) 4. Harv Pap Bot 14:111-128

Pabst GFJ, Dungs F (1975) Orchidaceae Brasilienses I. Kurt Schmersow, Hildesheim

Parkhurst DF (1978) The adaptive significance of stomatal occurrence on one or both surfaces of leaves. J Ecol 66:367-383

Porembski S, Barthlott W (1988) Velamen radicum micromorphology and classification of Orchidaceae. Nord J Bot 8:117-137

Pridgeon AM (1982) Diagnostic anatomical characters in the Pleurothallidinae (Orchidaceae). Am J Bot 69:921-938

Pridgeon AM (1987) The velamen and exodermis of orchid roots. In: Arditti J (ed) Orchid biology: reviews and perspectives IV. Cornell University Press, Ithaca, pp 139-192

Pridgeon AM (1994) Systematic leaf anatomy of Caladeniinae (Orchidaceae). Bot J Linn Soc 114:31-48

Pridgeon AM, Stern WL, Benzing DH (1983) Tilosomes in roots of Orchidaceae: morphology and systematic occurrence. Am J Bot 70:1365-1377

Pridgeon AM, Cribb PJ, Chase MW, Rasmussen FN (1999) Genera orchidacearum. General introduction, Apostasioideae, Cypripedioideae. Oxford University Press, Oxford

Pridgeon AM, Cribb PJ, Chase MW, Rasmussen FN (2003) Genera orchidacearum. Orchidoideae (part two), Vanilloideae. Oxford University Press, Oxford

Pridgeon AM, Cribb PJ, Chase MW, Rasmussen FN (2009) Genera Orchidacearum: Epidendroideae (part two). Oxford University Press, Oxford

Rasmussen H (1987) Orchid stomata-structure, differentiation, function and phylogeny. In: Arditti J (ed) Orchid biology: reviews and perspectives IV. Cornell University Press, Ithaca, pp 104-138

Salazar GA, Chase MW, Soto-Arenas MA, Ingrouille M (2003) Phylogenetics of Cranichideae with emphasis on Spiranthinae (Orchidaceae: Orchidoideae): evidence from plastid and nuclear DNA sequences. Am J Bot 90:777-795

Salazar GA, Cabrera LI, Madriñán S, Chase MW (2009) Phylogenetic relationships of Cranichidinae and Prescottiinae (Orchidaceae, Cranichideae) inferred from plastid and nuclear DNA sequences. Ann Bot 104:403-416

Sanford WW, Adanlawo I (1973) Velamen and exodermis characters of west African epiphytic orchids in relation to taxonomic grouping and habitat tolerance. Bot J Linn Soc 66:307-321

Silva CI, Milaneze-Gutierre MA (2004) Caracterização morfoanatômica dos órgãos vegetativos de Cattleya walkeriana Gardner (Orchidaceae). Acta Scientiarum 26:91-100

Silva IV, Meira RMSA, Azevedo AA, Euclydes RMA (2006) Estratégias anatômicas foliares de treze espécies de Orchidaceae ocorrentes em um campo de altitude no Parque Estadual da Serra do Brigadeiro (PESB)—MG, Brasil. Acta Bot Bras 20:741-750

Sinclair R (1990) Water relation in orchids. In: Arditti J (ed) Orchid biology: reviews and perspectives V. Timber Press, Oregon, pp 63-119

Stern WL (1997a) Vegetative anatomy of subtribe Orchidinae (Orchidaceae). Bot J Linn Soc 124:121-136

Stern WL (1997b) Vegetative anatomy of subtribe Habenariinae (Orchidaceae). Bot J Linn Soc 125:211-227

Stern WL, Judd WS (2002) Systematic and comparative anatomy of Cymbidieae (Orchidaceae). Bot J Linn Soc 139:1-27

Stern WL, Aldrich HC, Mcdowell LM, Morris MW, Pridgeon AM (1993a) Amyloplasts from cortical root cells of Spiranthoideae (Orchidaceae). Protoplasma 172:49-55

Stern WL, Morris MW, Judd WS (1993b) Comparative vegetative anatomy and systematics of Spiranthoideae (Orchidaceae). Bot J Linn Soc 113:161-197 
Wilkinson HP (1979) The plant surface (mainly leaf). In: Metcalfe CR, Chalk L (eds) Anatomy of the dicotyledons, 2nd edn. Clarendon Press, Oxford, pp 97-165

Zanenga-Godoy R, Costa CG (2003) Anatomia foliar de quatro espécies do gênero Cattleya Lindl. (Orchidaceae) do planalto central brasileiro. Acta Bot Bras 17:101-118
Zotz G (1999) What are backshoots good for? Seasonal changes in mineral, carbohydrate and water content of different organs of the epiphytic orchid, Dimerandra emarginata. Ann Bot 84:791-798 